УАК 1:323.272:141.7

DOI: 10.26565/2226-0994-2018-59-6

\title{
Нина Бусова
}

\section{РЕШЕНИЕ СОЦИААЬНОГО ВОПРОСА ИАИ ИНСТИТУЦИОНААИЗАЦИЯ СВОБОАЫ? (Х. АРЕНАТ О РЕВОАЮЦИИ)}

Статья посвящена критической реконструкции концепций революции и публичной свободы Ханны Арендт. Анализ текстов Арендт позволяет слелать вывод, что суть революции она виАит в восстановлении изначального, античного смысла политики, что означает учреждение таких форм правления, которые способны обеспечить политическую свободу гражАан, их право на участие в политических дебатах и принятии решений. Ни одна из революций не решила эту задачу. Современный опыт доказывает, что условием преодоления кризиса демократии яв яется развитие гражданского общества в направлениях, предлагаемых выдвинутыми Арендт концепциями публичной сферы и политической свободы.

Кмючевые слова: революция, свобода, действие, политика, публичная сфера, социальное.

История XX века, как отмечает Ханна Арендт, нанизана «на стержень революций» [Арендт, 2011, с. 356]. Волна Аемократических революций, захлестнувшая начало нынешнего века, свидетельствует о том, что эти слова применимы и к XXI столетию. Причем в большинстве случаев эти события, по мнению Ажонатана Шелла, подтвержАают акмуальность отстаиваемой Ханной Арендт концепции революции, поскольку «они скорее были нацелены на установление условий свободы, чем на решение социальных вопросов» [Schell, 2006, p. хxii]. ОАнако вряА Аи можно считать эту концепцию АренАт, как и её Аоктрину политического в целом, готовой парадигмой осмысления современного политического опыта. Скорее, слелует использовать «метод фрагментарного присвоения её политической мысли», как это сформулировала C. Бенхабиб [Benhabib, 1996, p. 173]. Творчество влиятельнейшего политического философа XX века отличается удивительной парадоксальностью. С одной стороны, её политическая мысль поражает чуткостью к новым проблемам, Ааёт продуктивный стимул Аля теоретического воображения, с Аругой стороны, она отАичается множеством противоречий. Обоснование этого положения явцяется щелью Аанной статьи.

Противоречив сам её подход к пониманию политики. АренАт, неизменно открещиваясь от звания философа и определяя себя как историка, настаива^а на жёсткой привязанности мысли к опыту, к событию [АренАт, 2002, с. 19]. Но вопреки провозглашаемому эмпиризму, её подход является нормативным, что характерно как раз Аля политической философии. Реконструкцию и оценку исторических событий она осуществляет, исходя из свого представления о классических ценностях общественной жизни. Парадоксальность её подхода ярче всего проявилась в исследовании феномена революции, основное содержание которого составляет сравнительный анализ Французской и Американской революций конца XVIII века. В их оценке она исходит из того, что «ГАавная идея революции - идея основания свободы, или, Аругими словами, учрежАения политического организма, гарантирующего пространство, гАе появАялась бы свобода» [Арендт, 2011, с. 170]. Итог применения этого критерия к реальным событиям оказался неутешительным: «... Неоспоримой истиной и одновременно прискорбным фактом явцяется то, что большинство так называемых революций <..> оказались неспособны даже обеспечить конституционные гарантии гражАанских прав и свобод», не говоря уже об установлении политической свободы [Арендт, 2011, с. 302-303]. ОАна Американская революция была успешной, но мишь наполовину, потому что «хотя революция и дала народу свободу, ей не удалось обеспечить пространство, где бы эта

() Бусова Н. А., 2018.

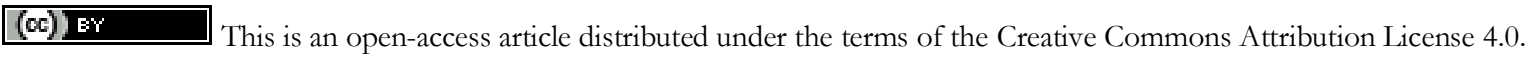


свобода могла реально существовать. Не сам народ, но только его выборные представители имели возможность заниматься "выражением, обсуждением и принятием решений”, то есть имели возможность деятельности, которая и есть собственно свобода в позитивном смысле этого слова» [АренАт, 2011, с. 326-327]. УтвержАая, что её мысль рожАается из опыта, Арендт на деле судит реальный исторический опыт по меркам своей идеальной модели революции.

Из каких нормативных посылок она исходит? КАючевыми категориями работ Арендт являются действие, свобода и публичная сфера, которые межат в основе её Аоктрины политического. Сама эта Аоктрина, по мысли автора, имеет исторический характер, она опирается на античный полис как на исходную модель, где политика зародилась и обрела свой изначальный, подлинный смыс, и гАе политическая Аеятельность ценилась так высоко, как никогАа ни до, ни после того [Арендт, 2002, с. 163]. Отстаиваемое АренАт понимание политического неразрывно связано с её теорией Аеятельности и трактовкой предназначения человека.

ИАя вразрез с установившейся в Новое время традицией отождествАять Аеятельность и труА, и при этом рассматривать остальные виды активности как вторичные, производные по отношению к труду, она различает три основные, несводимые один к Аругому виАа Аеятельной жизни: труд (работа), созАание (изготовление), Аействие (поступок). Каждый вид деятельности обеспечивает определённое необходимое условие человеческого существования и оценивается по своим критериям, в соответствии со своими ценностями [АренАт, 2000, с. 14]. ТруА - это Аеятельность, направленная на подлержание жизни на биологическом уровне, она обеспечивает сохранение живого организма и продолжение жизни рода. Ценности труда - жизнь, продуктивность, изобилие. Продукты труда неАолговечны, они потребляются вскоре после изготовления. Подчинённый необходимости, удовлетворению жизненных потребностей, труА «вращается в бесконечном повторении по неизменно возвращающемуся кругу, который предписан ему биологическим жизненным процессом» [Арендт, 2000, с. 126]. Создание производит специфически человеческую окружающую среАу, искусственный мир вещей, который Арендт нередко называет просто миром. Ценности создания - постоянство, стабильность, Алительность. Если продукты труда потребляются, то созАанные вещи используются, они Аолговечны и способны пережить своего создателя. Мир, явАяясь предметным образованием, получает свой смысл, только будучи сценой Аля поступка и слова, когАа он постоянно обсужАается Аюдьми.

В отличие от труда и созАания, Аействие (поступок) - это такой виА Аеятельности, который развёртывается без материальных посредников прямо межАу Аюдьми. Аействие и речь неразрывно связаны, они порождены «фактом множественности», то есть необходимостью совместного существования разАичных Аюдей. Результатом поступков и слов является «ткань межчеловеческой связи», которая через Аействие и речь не только создаётся и подАерживается, но и необратимо изменяется. «... Поступок есть политическая Аеятельность par excellence [по преимуществу]» [АренАт, 2000 с. 16]. Суть Аействия заключается в инициировании чего-то нового, неожиАанного, доселе небывалого. «... Аействовать и начинать нечто новое - одно и то же» [АренАт, 2000, с. 230]. Ценности Аействия - свобода, множественность, солидарность.

Понимание свободы у Арендт отличается от миберальной трактовки: свободу не следует смешивать ни со свободой частной инициативы при капитализме, ни с гражАанскими правами. Свобода в исходном смысле не явАяется также ни свободой мысли, как у стоиков в поздней античности, ни свободой воли, как в христианской философии. В античности, в её политической, дофилософской традиции свобода рассматривалась как атрибут действия, утверждает Арендт, и именно такое понимание свободы она принимает за исходное: «Аюди являтотся свободными - в отАичие от их владения даром стремиться к свободе - Аишь до тех пор, пока они действуют, и ни АО, ни после этого; ибо бъть свободным и действовать - это одно и то же» [АренАт, 2002, с. 161]. В античной традиции 
(в реконструкции АренАт) понятия свобода, Аействие и начало неразрывно связаны. Обращаясь к анализу греческих и матинских слов, обозначающих действие, Арендт утверждает, что они описывают такую сферу опыта, в которой понятия «быть свободным» и «начинать» (что-то новое) взаимосвязаны, а то и совпадают [Арендт, 2002, с. 174-175].

Свобода является предназначением человека. Арендт обосновывает это утверждение, ссылаясь на Августина Аврелия, с именем которого часто связывают введение в философию антропологического вопроса. В разных работах она вновь и вновь обращается к фразе Августина Блаженного из труда «О граде Божьем»: «Чтобы быть этому началу, был сотворён человек». Комментируя эти слова, она пишет: «Поскольку он является началом, человек может начинать; бъгть человеком и быть свободным - это одно и то же. Бог созАал человека, чтобы ввести в мир возможность начала, то есть свободу» [Арендт, 2002, с. 176]. Опираясь на идею Августина о том, что с сотворением человека в мир пришла свобода, способность начинать, Арендт развивает свою пользующуюся известностью концепцию натаАьности, рожАённости: «рожАаются АюАи и с ними новое начало, которое они способны проводить в жизнь благодаря своей рожАённости» [Арендт, 2000, с. 328]. Концепщия натальности как онтологической преАпосылки возможности свободы и действия (поступка) при всей её эффектности не преАставляется, на мой взгляА, Аостаточно обоснованной. РожАённость не является специфическим признаком человеческой экзистенции, человек разделяет это свойство со всем животным миром. И ссылка на Августина не вполне корректна, поскольку он апеллирует не к рожАению, а к сотворению человека. Кроме того, аподиктическим (по определению Арендт) его суждение является только в рамках христианской антропологии с её центральной идеей богоподобия человека.

Хотя все три вида активной жизни человека - труд, создание и Аействие необходимы Аля воспроизводства условий человеческого существования, действие явАяется высшим виАом Аеятельности, ибо в нём реализуется свобода. Аействие противоположно труАу, который направлен на удовлетворение потребностей, порождаемых необходимостью подцержания жизни. Но свободу нельзя приравнять к суверенности, то есть к способности полностью владеть собой и ходом событий. «... Мы хотя и способны к новому началу, но не в состоянии Аержать его поА контролем и предвилеть его последствия» [АренАт, 2000, с. 312]. ПослеАствия Аействия непреАсказуемы, как в силу того, что оно является проявлением свободы, способности начинать нечто новое, небывалое, так и потому, что действие происходит внутри сети человеческих отношений, внутри множественности. Каждый Аеятель, совершая поступок, вступает в сеть, сплетающуюся из действий Аругих акторов, и результат переплетения всех Аействий невозможно предвиАеть, исходя из намерений какого-то одного конкретного субъекта. Поэтому история, как результат действий Аюдей, также непредсказуема. Быть готовым К «чудесам» в политической сфере, то есть к чему-то неожиданному и непрогнозированному, явцяется, как ни параАоксаАьно, прояв ением реализма [Арендт, 2002, с. 178-180].

Но как в таком случае возможно хотя бы отчасти контролировать запущенные нами процессы, вносить какой-то порядок в совместную жизнь Аюдей? Противоядием от непредсказуемости действия является способность Аавать и сдерживать обещания, которую Арендт считает главнейшей из человеческих способностей в области политики. Связующая сила взаимного обещания кристаллизируется в институтах, в рамках которых возможна политическая деятельность. «... Законы и конституции, договора и союзы - все, в конечном счёте, вытекают из способности обещать и придерживаться обещаний переА существенной неопределённостью будущего» [Арендт, 2002, с. 173].

Арендт неоднократно указывала, что действие, неразрывно связанное с речью, считалось в античности собственно политической Аеятельностью. М. П. А’Энтривес (M. P. d’Entréves), известный исследователь творчества Арендт, обратил внимание на Авойственность её понятия «Аействие» и, соответственно, понимания сути 
политики. С одной стороны, поступки и слова создают «ткань межчеловеческой связи», сеть человеческих взаимоотношений, общий мир ценностей и убежАений [АренАт, 2000, с. 122, 248]. С Аругой стороны, «Аействуя и говоря, АюАи всякий раз обнаруживают, кто они суть, активно показывают Аичную неповторимость своего существа, как бы выступают на сцене мира» [Арендт, 2000, с. 234]. Опираясь на Ю. Хабермаса, А’Энтривес предлагает назвать эти Ава аспекта действия коммуникативным и экспрессивным действием [d'Entréves, 1994, pp. 84-85]. С учётом Аанной Авойственности становится понятным и расхождение в определении мотивации действия у Арендт. Она неизменно подчёркивает, что действие как проявление свободы человека не преследует утилитарные цели, в отличие от труда и создания, которые служат производству полезного, поскольку подчинены необходимости подАержания жизни. Но при этом АренАт называет мотивацией Аействия то «заботу об общих Аелах, о республике» [АренАт, 2000, с. 110], то честь, славу, Аостоинство, Аоблесть, совершенство [Аренат, 2002, с. 161]. Говоря языком Гегеля, Ф. Фукуямы и А. Хоннета, во втором случае речь илёт о борьбе за признание.

Но и в том, и в Аругом случае действие нужАается в общем пубиичном пространстве свободы, не подчинённом необходимости подАержания биологического процесса жизни, материальной нужде и потребностям. Это пространство, само явАяющееся продуктом поступка и слова, предостав яет как форум Аля колАективного обсужАения и принятия решений относительно организации совместной жизни, «общего мира», так и сцену, где человек может явить себя этому миру.

Таким пространством публичного, собственно политическим пространством являлся полис. В античных городах-государствах возникло принципиально важное условие возможности политики и свободы - чёткое разграничение публичного и частного: первому соответствует полис, или политическое пространство, второму - сфера домохозяйства и семьи. Полис - сфера свободы, свободы в Авояком смысле: отсутствия господства, принужАения со стороны Аругих Аюдей и отсутствия подчинения необходимости удовлетворять жизненные нужды и потребности. Наоборот, Аомохозяйство - сфера неравенства, принуждения со стороны главы семейства и порабощения необходимостью подАерживать жизненный процесс. Это сфера труда и созАания, деятельности утилитарной, служащей мишь цели жизнеобеспечения, то есть Аеятельности экономической, принципиально неполитической. Экономика - сфера частного интереса, политика - область заботы об общих делах. Частная сфера является условием возможности политики и свободы, потому что «удовлетворение жизненных нужА внутри Аомашнего хозяйства создаёт условия Аля свободы в полисе» [Аренат, 2000, с. 42].

Связь межАу свободой и политикой в её изначальном, исходном смысле АренАт определяет таким образом: «... Если мы понимаем политику как нечто производное от понятия полиса, её целью, или raison d’être [смыслом существования], Аолжно быть создание и сохранение пространства, где свобода может выступать как виртуозносты [Аренат, 2002, с. 163]. (Виртуозность характеризует совершенство исполнительского искусства, которое проявляется в самом исполнении, а не в конечном продукте, как в случае прикладных искусств, которые относятся к такому виду деятельности как создание).

Но в эпоху модерна, начиная с политических мыслителей XVII-XVIII веков, свободу отАеляют от политики. Целью политики стали считать обеспечение жизненных интересов и потребностей общества, а свободу начали рассматривать с точки зрения определения границ, которые правительство не Аолжно переступать, если только речь не илёт об обеспечении безопасности. АренАт связывает это с возникновением в Новое время феномена социального (Аругие термины Аля обозначения этого явления - социальность, социальная сфера, общество, социум). Социальное - это экономика, вышедшая за пределы Аомашнего хозяйства, «само ведение хозяйства и все занятия, прежде приналлежавшие 
к частной сфере семьи, теперь касаются всех, т.е. стали “коллективными" заботами» [АренАт, 2000, с. 45]. Социальность разрушает границу межАу частными и публичными Аелами, что ведёт к тому, что частный интерес оккупирует публичную, политическую сферу, вытесняя оттуда «заботу об общих Аелах, о республиике». Аеятельность, подчинённая биологической необходимости подцержания жизненного процесса, занимает пространство свободы. «Социум есть та форма совместной жизни, где зависимость человека от ему подобных ради самой жизни и ничего Аругого Аостигает пуб์личной значимости и где вследствие этого виды деятельности, служащие единственно подцержанию жизни, не только выступают на открытой публичной сцене, но и смеют определять собою мицо пуб̆личного пространства» [Арендт, 2000, с. 61-62]. Новое время перевернуло иерархию видов Аеятельности, впервые поставило на первое место труд, провозгласив его источником всех ценностей.

В обществе человек вступает в кооперацию с Аругими, но Авижим при этом частным интересом, потребностями индивидуального жизнеобеспечения. «... Новое время собственно вообше не отделяет и не отличает общественное от политического» [Арендт, 2000, с. 44]. Функционализация политики, подчинение её материальным интересам сделали возможным появление такого понятия как политическая экономия. В русле античной мысли оно воспринималось бы как оксюморон, противоречие в терминах, поскольку экономическое определялось тогАа как неполитическое. Сама наука политэкономия, возникшая вместе с социумом, исходит из предпосылки, выражающей суть социальности: искАючение Аействия как свободного поступка. Поведение человека понимается как жёстко обусловленное эгоистическим интересом и инстинктом приобретения. Не случайно важнейшим техническим инструментом политэкономии явАяется статистика, «ГАе подрасчётность человеческих реакций подразумевается уже сама собой» [АренАт, 2000, с. 55]. По следам политэкономии Аостаточно скоро пошли общественные науки, сводя человека Ао уровня жёстко обусловленного в своём поведении живого существа. История начинает пониматься как «естественный процесс», подчинённый необходимости, вместо истории как ткани, сплетённой из человеческих действий и событий.

Причины подъёма социального и стирания грани межАу частной и публичной сферой Арендт видит как в экономике, так и в политике. Разрастанию социальности способствует развитие капиталистической рыночной экономики, когда всё становится объектом производства, присвоения, обмена и потребления. Быстрый и неуклонный экономический рост означает безудержную экспансию частной сферы, проникновение частных интересов в публичную сферу [Арендт, 2011, с. 351]. С Аругой стороны, социализации публичной жизни способствоваца Французская революция, на раАикаАьной фазе которой произошло смещение акцента с утверждения принципов свободы на решение «сочиального вопроса», т. е. на освобождение массы бедных от нищеты. После того, как жирондисты оказались не в состоянии принять конституцию и установить прочное республиканское правление, к власти при подлержке бедноты пришли якобинцы, побудительным мотивом которых стало сострадание к острой нужде масс. Свобода оказа^ась подчинённой необходимости, жизненным нуждам. Аостоянием публичности стало то, что принаАлежит к частной сфере. БАагородная страсть сострадания требует быстрого и решительного Аействия, поэтому «отбрасываются все Аолгие и утомительные процессы убежАения, переговоров и компромиссов, которые и состав яют суть политики, $<\ldots>$ в ход илут средства насилия» [Арендт, 2011, с. 115]. Якобинская диктатура закончилась царством террора.

Арендт настаивает, что опыт революций «неопровержимо свидетельствует о том, что Аюбая попытка решить социальный вопрос политическими среАствами оканчивается террором и что именно вследствие террора революция терпит поражение» [АренАт, 2011, с. 151]. Как видим, с точки зрения автора, террор является поражением революции, а не просто её негативной, разрушительной стороной, которую 
Арендт стремится отделить от позитивной, конструктивной, как прочитывает А. В. Магун главу «Социальный вопрос» книги «О революции» [Магун, 2008, с. 360]. Избавление от нищеты, полагает Арендт, может быть Аостигнуто только через развитие технологии, стремление решить этот вопрос политическими средствами тщетно и опасно. ОАнако все последовавшие революции «оказались во власти чар французской революции в общем и во власти социального вопроса в частности» [АренАт, 2011, с. 77]. Закончившаяся катастрофой Французская революция, тем не менее задала образец Аля понимания революций XIX-XX веков. В умах и революционеров, и теоретиков революции социальный вопрос затмил интерес к формам правления, способным обеспечить пространство свободы, интерес, который, по мнению Арендт, составляет суть революций.

Но в таком случае, на каком основании Арендт утвержАает, что установление пространства свободы является главной идеей революции? Работа «О революции» позволяет преАложить два объяснения. АренАт считает типичной ошибкой современной философии то, что «она понимает и описывает сферу человеческого Аействия не с позиции “актёра", некоего Аействующего Аица, а с позиции наблюдающего за действием зрителя» [АренАт, 2011, с. 65]. Сами же участники Авух великих революций конца XVIII века, Американской и Французской (на её начальных этапах), говорили о вдохновлявшем их духе свободы, что Арендт подтвержАает многочисленными цитатами.

Второе объяснение указывает на парадоксальность трактовки революции у Арендт. Она настойчиво повторяет, что современное понимание революции, возникшее в конце XVIII века, неразрывно связано с представлением о совершенно новом этапе истории. И в то же время, говоря о сути революции, сама фактически возвращается к первоначальному пониманию этого слова как реставрации, восстановления. В конечном итоге, по Арендт, главная идея револючии заключается в восстановлении изначального, античного смызсла политики. К такому выводу можно прийти, сопоставАяя две цитаты, уже приводившиеся нами. Первая: «... ГАавная идея революции - идея основания свободы, или, Аругими словами, учреждения политического организма, гарантирующего пространство, гАе появлялась бы свобода» [Арендт, 2011, с. 170]. И вторая цитата: «... Если мы понимаем политику как нечто производное от понятия полиса, её целью, или raison d'être [смыслом существования] Аолжно быть создание и сохранение пространства, где свобода может выступать как виртуозность» [Арендт, 2002, с. 163]. Аа АренАт и сама говорит об этом прямо: «Новый опыт свободы и стал, собственно, открытием революции, или скорее заново совершённым открытием - он был достаточно хорошо известен во времена греческой и римской Античности, но после падения Римской империи был утрачен» [АренАт, 2011, с. 38].

ЕАинственной успешной революцией, Аа и то только наполовину, оказалась Американская революция. Аля понимания этой оценки следует иметь в виАу проводимое Арендт разАичение межАу освобождением и свободой. Она называет их двумя задачами, решением которых революции Нового времени занимались одновременно. Освобождение есть условие, предпосылка свободъ. Понятие свободы, содержащееся в идее освобождения негативное, поскольку оно подразумевает избавление от несправеАливых ограничений, от угнетения, господства, тирании. Результатом освобождения являются гражАанские права, закреплённые в конституции [Арендт, 2011, с. 36-37]. Но освобождение и свобода не тождественны, и гражданские права, завоёванные в результате освобождения, не следует смешивать со свободой, а гарантирование их не может стать целью и содержанием свободы. Позитивное понятие свободы подразумевает не ограничение власти, но её установление. Свобода заключается в праве гражданина на участие в публичных делах, в политических дебатах и принятии решений. Иначе говоря, по АренАт, свобода в Аействительном смысле этого слова является политической свободой, которая «Аибо означает право “быть участником в управлении", кибо не означает ничего» [Арендт, 2011, с. 303]. Свобода требует установление республики как res publica, то есть в буквальном смысле «оббщей вещи». 
Американская революция была успешна в том, что было основано новое государство. После того, как Аекларация независимости отменила власть английской короны, главной задачей революции было создание новых центров власти. Именно это стало целью как конституции штатов, так и последовавшей за ними конституции союза. «... Аействительным содержанием американской конституции, - по мнению Арендт, было не гарантирование гражАанских прав, а установление совершенно новой системы власти» [АренАт, 2011, с. 202]. При этом основатели республики побеспокоились об обеспечении прав и свобод гражАан, о конституционной защите их от опасностей со стороны государства (то есть об освобождении). Именно в эффективности защиты гражданских прав европейские эксперты всегАа видели главное Аостоинство американской конституции.

Аейственность американской конституции объясняется авторитетом, которым она пользовацась с самого начала: «... Конституции стали “покцоняться”, едва она вступила в силу. <..> Именно в этом отношении Американская революция наиболее явно отличалась от всех Аругих, последовавших за ней» [Арендт, 2011, с. 275]. Наоборот, на европейском континенте, после Первой мировой войны и низвержения монархического правления в ряде стран, были приняты конституции, которые хотя и были составлены экспертами на основе американского образца, однако вызывали недоверие у народа. Отсутствие авторитета стало бичом и французских конституций: «... Четырнадцать конституций Франции межАу 1789 и 1875 годами привели к тому, что ещё Ао мавины послевоенных конституций в XX веке само слово “конституция" стало звучать как издевательство» [Арендт, 2011, с. 200].

Основу авторитета американской конституции и важнейшую причину успеха американской революции АренАт вилит в полуторавековом опыте самоуправления, который предшествовал событиям конца XVIII века. «ЗАой рок Французской революции заключался в том, что ни одно из конституционных собраний не располагало Аостаточным авторитетом Аля того, чтобы дать стране конституцию» [Арендт, 2011, с. 227]. Члены этих собраний не могли апелмировать ни к предыдущей конституции, ни к божественным правам, как монархи. Они столкнулись с самой сложной проблемой революции, проблемой мегитимности конституции и устанав иваемой ею новой системы власти.

Эта проблема не вставала перед создателями конституций штатов, а затем и Конституции Соединённых штатов. «... Огромной удачей Американской революции было то, что народ колоний ещё Ао конфликта с Англией был организован в самоуправ яющиеся общества, группы» [АренАт, 2011, с. 227]. Авторитет конституций выводился из нижестоящих авторитетов: «Делегаты местных конгрессов или народных конвентов, подготовившие проекты конституций штатов, получили свои полномочия от многочисленных нижестоящих органов: округов, районов, городских и сельских общин» [АренАт, 2011, с. 227-228]. Основой управления обществом являлись самоуправляющиеся городские и сельские общины, где законодательная и исполнительная власть были максимально приближены к населению, поскольку члены городского управления и муниципальные чиновники ежегодно избирались на собрании общины.

Институты самоуправления сложились в ходе колонизации континента задолго до конфликта колоний с Англией. Начало этому положил «Мэйфлауэрский Аоговор», состав енный на борту судна «Мэйфлауэр» отцами-пилигримами, основавшими в 1620 году первую постоянную колонию в Новой Англии. (Как заметил Токвиль, именно в штатах Новой Англии принципы общинного устройства получили наибольшее развитие [Токвиль, 1992, с. 65]). В этом соглашении подписанты обязались объединиться в «гражАанский политический организм» ради порядка и выживания, а также создавать такие справедливые и одинаковые Аля всех законы, которые будут считаться наиболее соответствующими общему благу колонии, и которым они обещают подчиняться. Этот Аоговор составиц основу Аля самоуправления в колонии. Аналогичная ситуация 
повторилась при основании следующих поселений: колонисты создаваАи Аля себя законную власть путём заключения договоров. Появившиеся позднее королевские хартии не учрежАали, а только санкционировали уже утвердившуюся систему правления. Поэтому конфликт и разрыв колоний с Англией, в результате чего королевские хартии Аишились силы, не отбросил колонистов в «естественное состояние» анархии, беззакония и безвластия. Они продолжали подчиняться законам и органам управления, авторитет которых был основан на многочисленных взаимных обещаниях и соглашениях.

Как стали отмечать уже в конце XVIII века, соглашения в колониях представ яяют собой уникальный в истории случай реализованного в жизни общественного Аоговора как акта основания политического сообщества. При этом колонисты не могли ничего знать о теории общественного Аоговора, Ааже если бы интересовались политической философией: Мэйфмауэрский Аоговор был составлен за тридцать мет Ао публикации

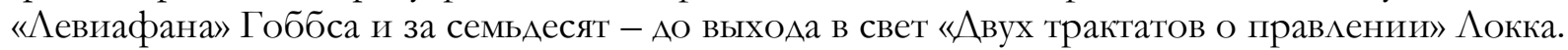
Принципиальное отличие реального общественного Аоговора, заключавшегося американскими колонистами, от теоретической модели Гоббса и Аокка заключается в том, что участники первого Аоговора, создавая путём взаимных обещаний и обязательств политическое сообщество, обретали сообща власть, тогда как во втором случае каждый член общества уступает свою отдельную власть государству, соглашаясь, чтобы им управ яяи.

По мнению Арендт, в историческом опыте американских колоний выразилась суть власти. «... ВАасть возникает там и в том случае, где Аюди объединяются вместе с целью действия, и исчезает, когда они расходятся и оставляют Аруг Аруга в одиночестве. Тем самым обязательства и обещания, объединения и соглашения суть способы, посредством которых власть подАерживает своё существование; где и когда Аюдям удаётся сохранить в неприкосновенности вАасть, зародившуюся среди них в ходе конкретного Аействия или Ае^а, они уже участвуют в процессе основания; конституции, законы и институты, возводимые ими при этом, жизнеспособны только в той мере, в какой они способны сохранить в себе раз возникшую власть живого действия» [АренАт, 2011, с. 241]. В свете этого становится понятным, почему Арендт считает способность Аавать и сдерживать обещания главнейшей из человеческих способностей в области политики: совместное Аействие $ю$ юей порождает власть, обещания и создаваемые ими обязательства её сохраняют.

Аеятели американской революции могли опереться на уникальный опыт Аореволюционной Америки, не имевший аналогов опыт сознательного целенаправленного создания публичных органов и институтов, что называется ex nihilo. «Поскольку соглашения в колониях первоначально заключались безо всякой апелцяции к королевской власти, Аело предстало так, как если бы революция вернула процессу заключения соглашений его первозданный виА, который он имел в первые Ани колонизации» [Арендт, 2011, с. 231]. В Старом Свете не было такого опыта, как не было и самоуправляющихся общин, которые, как показывает Токвиль, составАяли основу, базовый уровень системы управления штатов, объединившихся затем в союз [Токвиль, 1992, с. 64-91]. В этом заключается главная причина разных последствий Американской и Французской революций.

Второй немаловажной причиной успеха Американской революции было, по мнению Арендт, отсутствие нищеты в Новом Свете. Сравнивая успешную американскую и неудачную французскую революции, она утверждает: «Своим успехом американская революция обязана не только мудрости основателей республики <...> Причиной успеха и одновременно неудачи было одно: отсутствие бедности в Америке и её наличие во всём остальном мире» [Арендт, 2011, с. 87]. Поэтому социальный вопрос не играА никакой роли в американской революции, тогАа как во французской революции он вышел на первый план, что закончилось террором и революционными войнами. 
И всё же американская революция была успешной мишь наполовину: «... Несмотря на все свои достижения, американская революция, тем не менее, не положила начало novиs ordo saeclorum [новому порядку веков]» [Арендт, 2011, с. 87]. Были созданы новое государство и эффективно защищающая гражАанские права конституция, которая стала краеугольным камнем «американской гражАанской религии» (Роберт Белла). Аругими словами, была успешно решена первая задача революции - освобождение, Аостижение негативной свободы. Но американцам не удалось институционально закрепить возможность гражАан быть свободными в позитивном смысле этого слова, то есть «действовать самостоятельно и участвовать в публичных делах и решении политических проблем, которые приносит каждый новый Аень» [АренАт, 2011, с. 349]. Замена прямого политического действия народа представительным правлением означает, что каждый член общества может почувствовать себя гражданином, участником в управлении только в день выборов. Это ведёт к потере интереса народа к публичным делам, к потере революционного духа, который Арендт отожАествАяет со страстью к политической свободе.

Арендт видит две причины такой неудачи американской революции. Первая связана с недооценкой основателями Соединённых Штатов значения городских общин и собраний как форм прямого политического участия народа. Поэтому они не смогли инкорпорировать их ни в конституции штатов, ни в федеральную конституцию. Все существенные политические дела взяли на себя правительства штатов и федеральное правительство [Арендт, 2011, с. 327-328].

Вторая причина заключается в том, что социальный вопрос, которого не знала американская революция, настиг Америку в XIX-XX вв., правАа, в более мягкой форме, чем в Европе. Если в начале колонизации переселенцами, религиозными Аиссилентами, Авигало стремление к свободе, то в XIX-XX веке массовая эмиграция из Европы превратилась в бегство от бедности. «Американская мечта» об установлении свободы трансформировалась в мечту об изобилии, об удовлетворении нужА потребительского характера.

В контексте Французской революции социальный вопрос представал в форме проблемы преодоления массовой нищеты, в Америке он превратился в вопрос обеспечения колмективного благосостояния. «После того, как революционный Аух был забыт, от них (от принципов публичной свободы, заботы об общем благе.-Н.Б.)

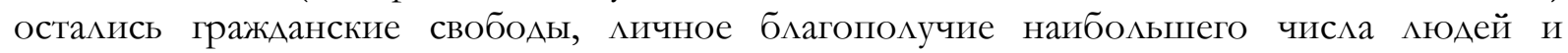
общественное мнение как величайшая сила, управляющая эгалитарным демократическим обществом. Произошедшая трансформация с большой точностью соответствует вторжению общества в сферу публичности: так, словно исконно политические принципы были переведены в социальные “ценности”» [Арендт, 2011, с. 306-307]. Целью конституции стали считать не обеспечение права гражданина участвовать во власти, в решении политических проблем, а защиту индивида от действий власти.

Социальный вопрос в форме совокупности вопросов, относящихся к колмективному благосостоянию, становится главным в современном государстве всеобщего благоденствия. А это означает, по мнению Арендт, упадок политики, которая вытесняется административными методами управцения, ибо только этими методами могут решаться такие вопросы. «... В государстве всеобщего благоденствия в конечном счете все политические вопросы являются задачами администрирования, которые должны решаться экспертами» [Арендт, 2011, с. 380]. Выход на первый план интересов потребительского характера ведёт к утверждению деполитизирующего бюрократического правления. Таков итог социальной формы политики современных обществ, когАа политические ценности участия гражАан в правлении вытесняются социальными ценностями общественного благосостояния.

Центральная проблема революции - институционализация политической свободы - так и не была решена ни одной из них. Неудачей закончились все попытки установить политическое пространство пуб̆личной свободы, гАе Аюди как свободные и 
равные граждане могли бы сами решать свои общие проблемы. Представительная демократия, утвердившаяся в результате революций, ведёт в конечном счете к кризису Аемократической мегитимности, поскольку является вцастью Аля народа, но не властью народа. Граждане свободны только в «негативном смысле». Их политическая свобода ушла к политическим партиям и преАставительным органам. Это неизбежно при такой форме правления, ибо, как отмечает АренАт, «единственное, что может быть представлено и Аелегировано - это только интерес и забота о благосостоянии избирателей, но никак не их способность к Аействию и мнению» [Арендт, 2011, с. 374]. Народ имеет власть только во время выборов, а потом надолго уходит со сцены политической жизни. Короткие фазы активности и чувства причастности к обустройству совместной жизни сменяются Аолгими периодами пассивности, утраты илАюзий, разочарования и потери интереса к публичным Аелам.

Согласно Арендт, обоснованность притязаний политической системы на Аемократическую мегитимность определяется степенью публичной свободы гражАан, возможностью активного участия в решении общих проблем. Нужна альтернатива преАставительному правлению, которая может созАать пространство политической свободы. Парламентской партийной системе она противопоставляет систему советов, с развитием которой связывает свои надежАы на возрожАение политики в поАлинном смысле. Советы Арендт описывает как «совершенно новую систему правления, с новым публичным пространством Аля свободы, конституированным и организованным в ходе самой революции» [Арендт, 2011, с. 347].

Партийная и советская система возникли в один и тот же исторический момент. В ходе Французской революции спонтанно образуются народные общества, целью которых был не выбор депутатов в Национальное собрание, а совместные занятия делами, представ яющими общественный интерес. Французские революционные общества, по мнению Арендт, «с почти сверхъестественной точностью предвосхитили те Räte, советы, которым назначено было яв яться на авансцену истории на протяжении XIX и XX веков в ходе практически каждой революции, которую бы мы могли назвать подлинной. Они возникали всякий раз как спонтанно сложившиеся органы народного управления, не только независимо от каких-либо революционных партий, но и неожиАанно Аля их мидеров» [Арендт, 2011, с. 347].

ОАновременно с этими прообразами советов появАяются прообразы партий парламентские фракции, которые впоследствии стали основой партийной системы. Партии в современном смысле слова формируются позднее, в результате расширения избирательного права в XIX веке. В отличие от советов партии нацелены не на прямое участие в публичных делах, а на выдвижение кандидатов в депутаты и обеспечение им подмержки народа. Партия представАяет собой придаток парламентской фракции, существующей реаАьно или являющейся целью партийной активности. Если же партия сама становится субъектом политического Аействия, то это ведёт к крушению парламентаризма.

С самого момента зарождения Авух систем правления началось их противостояние: «... Уже в ходе Французской революции мы имели дело с конфликтом межАу современной партийной системой и самой революцией порожАённой новой государственной формой» [Арендт, 2011, с. 344]. Ааже якобинцы, отстаивавшие права народных обществ переА Национальным собранием, приля к власти, стали устанавливать контроль наА ними, объявив неподконтрольные им общества незаконными. КонфАикт межАу партиями и советами разгорался во всех последующих революциях, причём мевые или революционные партии оказались не менее вражАебными по отношению к советской системе, чем партии консервативные или реакционные. Ааже более того, по мнению Арендт, в поражении системы советов профессиональные революционеры и революционные партии сыграли решающую роль. «... НаАежАа на преобразование государства, на новую форму правления, которая позволила бы каждому члену 
современного эгалитарного общества стать “участником" в ведении публичных дел, оказалась похороненной в катастрофах революций XX века» [Арендт, 2011, с. 369].

Проект институционализации политической свободы, выдвинутый самой АренАт, выгАядит утопическим и отнюдь не Аемократическим. Она предлагает пирамидально организованную систему прав ения, базовый уровень которой состав яюют элементарные советы, «возникающие везде, где Аюди живут и работают вместе» [Арендт, 2011, с. 388]. Они формируются не путём выборов, а в результате самоотбора инициативных, ответственных Аюдей, готовых посвятить себя общему делу. Аругими словами, Аюдей, обладающих политическими качествами. Арендт не питает илАюзий относительно того, что вся совокупность гражАан облаАает этими качествами: «... Политический образ жизни никогда не был и никогАа не будет образом жизни многих, Ааже несмотря на то, что политика по определению затрагивает более чем многих, конкретно - всю совокупность гражАан» [Арендт, 2011, с. 385]. Большая часть населения не отличается ни компетентностью в политических вопросах, ни просто интересом к политике.

На базовом уровне происходит организация политической элиты народа, «которую никто не выбирал и которая сама себя создаёт» [Арендт, 2011, с. 390]. Формирование совета более высокого уровня осуществляется уже через выборы депутатов от низового уровня, что повторяется на каждом последующем слое пирамиды. «Конечно, такая в подлинном смысле слова “аристократическая” форма правления означала бы конец всеобщим выборам в том смысле, в котором мы понимаем их теперь; ибо только те, кто $<\ldots>$ показал, что стремится к чему-то большему, нежели просто Аичное счастье, и озабочен делами всего мира, имеют право быть услышанными при ведении Аел республики» [АренАт, 2011, с. 390-391].

В духе Вебера АренАт критикует партии не за создание политической элиты, а за то, что в рамках бюрократизированной партийной системы политика стала профессией и карьерой, и соответственно отбор элиты осуществцяется отнюдь не по политическим качествам. Проблема не в элите как таковой, а в том, что туда не могут войти те немногие, принадлежащие ко всем слоям общества, кто стремится к политической свободе и готов взять на себя ответственность за публичные дела. Непринадлежность к политической элите, формирующейся путём самоотбора, не имела бы принижающего характера, потому что она являлась бы результатом собственного выбора «свободы от политики», которую Арендт считает одной из важнейших негативных свобод, неизвестной античности и составляющей весомую часть христианского наследия [Арендт, 2011, с. 391].

На мой взгляА, политический проект Арендт никак нельзя охарактеризовать в терминах оппозиции межАу преАставительной и прямой Аемократией, вопреки распространённой точке зрения, среди сторонников которой можно встретить весьма авторитетных авторов, таких например, как Альбрехт Велммер [Wellmer, 2000, p. 224].

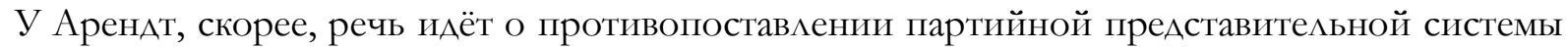
и политической свободы. Прямая демократия подразумевает значительно бо $\square$ ьшую степень колцективной политической Аееспособности совокупности гражАан, чем та, на которую полагается АренАт.

Проблема представительства Аействительно является основной болевой точкой современной Аемократии. При самой совершенной избирательной системе представительная Аемократия является «эпизодической Аемократией выборов» (Пьер Розанвалон), когда народ обладает властью только в Ани выборов, а затем она отходит к его избранникам. Но Арендт, по сути, предлагает Аишить бо $\square$ Аьшую часть гражАан и этой эпизодической власти. И здесь она явно недооценивает влияние процессов Аемократизации, начавшихся с конца XVIII века и неудержимо набирающих всё бо $\square$ Аьшую силу. Если судить по количеству активистов гражАанского общества, то процент Аюдей, склонных к «политическому образу жизни» в понимании АренАт, Аействительно невысок среди всех слоёв общества. Но спектр форм политической вовлечённости Аюдей Аостаточно широк, и та значительная часть населения, чья 
политическая активность ограничивается участием в выборах, вряА ми удовлетворится негативной «свободой от политики». ПреАставительство Ааёт возможность косвенного участия в политике тем гражАанам, которые чувствуют свою ответственность за организацию совместной жизни, но в силу темперамента и склонностей не расположены к политической деятельности и публичной жизни. Эпизодическая власть избирателя - это именно вАасть, которая превращает подданного в гражАанина, в чём и состоит суть Аемократической революции по известному определению Т. Парсонса.

Аругое Аело, что эта эпизодическая демократия выборов нуждается в дополнении формами постоянно Алящейся Аемократии прямого политического действия самих граждан. Это нужно и Аля контроля со стороны общественности за текущей Аеятельностью институтов как законодательной, так и исполнительной власти, и Аля того, чтобы предотвратить возможное искажение самого процесса выборов, которое свело бы к нулю власть избирателя. История не подтвердила эффективность советов ни в качестве организации законодательной власти, альтернативной существующей парламентской преАставительной системе, ни в качестве Аополнения к партийной системе правления. И тем не менее размышления Арендт о том, как политическая свобода Аолжна быть обеспечена в современных демократиях, остаются актуацьными.

В последние десятилетия и на практике, и в теоретической рефлексии на передний план выходит гражАанское общество как способ организации спонтанной политической активности общественности, составцяющий противовес (но не альтернативу!) формальным политическим институтам. Аобровольные организации и ассоциации гражданского общества формируются не через выборы (как представительные органы) или назначение (как исполнительная власть), а путём самоотбора. Цели этих организаций, также как и способы самоуправления, определяются самими свободными и равными участниками.

В функционировании этих Аобровольных ассоциаций есть один чувствительный момент: каким образом может финансироваться гражАанская активность, которая по определению не является профессией и карьерой, в отличие от деятельности участников формализованной политической системы? На Аанный момент наиболее распространённой формой общественного спонсирования неприбыльных проектов является грантовая подАержка. На постсоветском пространстве она недостаточно развита, к тому же получатели такой помощи нередко клеймятся как грантоеды, агенты иностранного влияния или выразители интересов олигархов. (Примечательно, что такие обвинения аАресуются именно представителям гражданского общества, не затрагивая Аеятелей науки и культуры, которые в первую очередь пользуются грантовой подАержкой). УАьрих Бек, один из самых проницательных социальных теоретиков современности, полагает, что укреплению гражАанского общества, разрушающего монополию политической системы на политику, будет способствовать гражданское пособие. ИАея гражАанского пособия, обеспечивающего прожиточный минимум и выплачиваемого государством всем взрослым гражданам, последние десятилетия активно обсуждается в связи с неумолимым ростом безработицы вследствие автоматизации производства. Но Бек подчёркивает важность этой идеи (АО сих пор кажущейся многим утопической) и Аля перспективы сохранения и укрепления демократии: «ГражАанские инициативы благодаря гражАанскому пособию Аелаются самостоятельными в материальном отношении и становятся дееспособными» [Бек, 2001, с. 245].

АренАт не затрагивала тему гражАанского общества, которая при её жизни пребывала в глубоком забвении. Возрождение интереса к ней началось в 1980-е годы в связи с нарастанием сопротивления гражАан тотаАитарной государственной власти в Центральной и Восточной Европе [Кин, 2001, с. 15-16]. Но ассоциации гражАанского общества - как формы активного участия граждан в решении общих проблем - по принципам организации сходны с советами базового уровня в описании Арендт. В предложенном ею политическом проекте не рассматривается вопрос материального 
обеспечения гражАан, которые выбирают политический образ жизни, не превращая его при этом в профессию и карьеру. ОАнако в своей реконструкции изначального, исходного понимания политики как производной от понятия полиса она подчёркивала, что условием возможности политической свободы является удовлетворение жизненных потребностей. Нетрудно Аогадаться, на чьей стороне оказалась бы Арендт в современных дискуссиях межАу сторонниками и противниками идеи гражАанского пособия, или, как его чаще называют в последние годы, безусловного базового дохода.

\section{СПИСОК ИСПОАЬЗОВАННЫХ ИСТОЧНИКОВ}

Арендт X. Vita activa, или о деятельной жизни / пер. с нем. и англ. В. В. Бибихина. Санкт-Петербург: Алетейя, 2000. 437 с. $321 \mathrm{c}$.

Аренлт Х. Між минулим і майбутнім / пер. з англ. В. Черняк. К.: Аух і Аітера, 2002.

Арендт Х. О революции / пер. с английского И. Косич. М.: Европа, 2011. 464 с.

Бек У. Что такое глобализация? / пер. с нем. А. Григорьева и В. Седельника. М.: Прогресс-Традиция, 2001. 304 с.

Магун А. В. Отрицательная революция: к деконструкции политического субъекта. Санкт-Петербург: Издательство Европейского университета в Санкт-Петербурге, 2008. $416 \mathrm{c}$.

Кин Аж. Аемократия и гражданское общество / пер. с англ. М. А. Абрамова. Москва: Прогресс-Традиция, 2001. 400 с.

Токвиль А. Ае. Аемократия в Америке / пер. с франц. В. Т. Олейника, Е. П. Орловой, И. А. Малаховой, И. Э. Иванян, Б. Н. Ворожцова. Москва: Прогресс, 1992. $554 \mathrm{c}$.

Benhabib S. The Reluctant Modernism of Hannah Arendt. Thousand Oaks: Sage Publications, 1996. 247 c.

D’Entréves M. P. The Political Philosophy of Hannah Arendt. London: Routledge, 1994.

Shell J. Introduction to Hannah Arendt's On Revolution. New York: Penguin Classics, 2006. pp I-XI.

Wellmer A. Arendt on Revolution. Villa D. (Ed.). The Cambridge Companion to Hannah Arendt. Cambridge: Cambridge University Press, 2000. pp. 220-244.

\section{Бусова Нина Андреевна}

Аоктор философских наук, профессор кафедры теоретической и практической фисофии имени профессора И. Б. Шаца

Харьковский национальный университет имени В. Н. Каразина

площадь Свободы, 6, Харьков, 61022

E-mail: busova_nina@ukr.net

ORCID: https://orcid.org/0000-0001-7221-8664

Статья поступила в редакцию: 23.10.2018

У тверждена к печати: 27.11.2018

\section{РІШЕННЯ СОЦІААЬНОГО ПИТАННЯ ЧИ ІНСТИТУЦІОНААІЗАЦІЯ СВОБОАИ? (Г. АРЕНАТ ПРО РЕВОАЮЦІЮ)}

\section{Бусова Ніна Андріївна}

Аоктор філософських наук, професор кафедри теоретичної і практичної філософії імені професора Й. Б. ШаАа

Харьківский національний університет імені В. Н. Каразіна

майдан Свободи, 6, Харків, 61022

E-mail: busova_nina@ukr.net

ORCID: https://orcid.org/0000-0001-7221-8664 
Стаття присвячена критичній реконструкції концепцій революції і публічної свободи Ганни Арендт. Показано, що піАхіА АренАт до розуміння політики, зокрема й феномена революції, $\epsilon$ нормативним, всупереч заявленому емпіризму. Вона наполягає на тому, що головною іАеєю всіх революцій є встановлення політичного простору свободи громадян, і водночас піАкреслює, що жодна революція не вирішила це завдання. Розглядаються нормативні посилки, на підставі яких Арендт судить реальний історичний досвіА - ії трактування Аії, свободи і публічної сфери. Свобода розуміється як зАатність ініціювати щось принципово нове, вона є призначенням Аюдини й реалізується в Аії, яка ототожнюється з політичною діяльністю. Аія потребує загального пуб์ ічнного простору свободи, який непіАпорядкований необхіАності задовольняти матеріальні потреби Аля піАтримання біологічного життевого процесу. Розмежування публічного простору і приватної сфери, яке виникло в античному полісі, є умовою можливості політики та свободи: політика царина турботи про загальні справи, приватна сфера піАпорядкована необхіАності задоволення матеріальних потреб. Це розмежування було зруйновано в Новий час з появою соціального, коли приватний інтерес окупував публічну політичну сферу. Аналіз текстів Арендт дозволяє зробити висновок, що суть революції вона бачить у відновленні початкового, античного сенсу політики, що означає встановлення таких форм правління, які зАатні забезпечити політичну свободу громаАян, їхнє право на участь у політичних дебатах і прийнятті рішень. Жодна з революцій не вирішила це завдання, оскільки в умах як учасників революції, так і іï теоретиків на перший план вийшло «соціальне питання», тобто проблема забезпечення колективного Аобробуту, що повинна вирішуватися аАміністративними методами управління, а не політичними засобами. Представницька демократія, яка утвердилась в результаті революцій, веде, зрештою, Ао кризи демократичної мегітимності, оскільки політична свобода громадян пішла до виборних органів. Сучасний АосвіА Аоводить, що умовою подолання кризи демократії є розвиток громадянського суспільства в напрямках, пропонованих висунутими Арендт концепціями публіічної сфери й політичної свободи.

Ключові слова: революція, свобода, Аія, політика, публиічна сфера, соціальне.

\title{
SOLUTION OF SOCIAL QUESTION OR INSTITUTIONALIZATION OF FREEDOM? (H. ARENDT ON REVOLUTION)
}

\author{
Busova Nina A. \\ Doctor of Science, Professor, Department of Theoretical and Practical Philosophy \\ named after Professor J. B. Schad \\ V. N. Karazin Kharkiv National University \\ 6, Svobody sqr., 61022, Kharkiv, Ukraine \\ E-mail: busova_nina@ukr.net \\ ORCID: https://orcid.org/0000-0001-7221-8664
}

\begin{abstract}
The paper offers a critical reconstruction of Arendt's concepts of revolution and public freedom. It is shown that, in spite of her self-proclaimed empiricism, Arendt's approach to understanding politics, including the phenomenon of revolution, is normative. She insists that the main idea of all revolutions is the constitution of a political space of public freedom, and at the same time emphasizes that none of the revolutions has solved this task. Normative premises, on the basis of which Arendt judges the real historical experience, are considered: her interpretations of action, freedom and public sphere. Freedom is understood as the capacity to initiate something new, it is man's destination and is expressed in action, which is identified with political activity. The action needs a common public space of freedom, which is free from the necessity to satisfy material needs for the maintenance of the biological life process. The distinction between public space and private sphere, which arose in the ancient polis, is a condition of the possibility of politics and freedom: politics is a realm of concern for public affairs, the private sphere is subject to the necessity to meet material needs. This distinction was destroyed in modern era with the advent of the social, when private interest occupied the public political sphere. Analysis of Arendt's texts leads to the conclusion that she sees the essence of the revolution in the restoration of the original,
\end{abstract}


ancient meaning of politics, which means the establishment of such forms of government that can ensure the political freedom of citizens, their right to participate in political debates and decision making. None of the revolutions solved this problem, because in the minds of both participants and theorists of revolution the "social question" came to the fore, that is, the problem of ensuring collective welfare, which should be solved by administrative methods of management, and not by political means. Representative democracy, established as a result of revolutions, in the end leads to a crisis of democratic legitimacy, since citizens have lost their political freedom to representative bodies. Contemporary experience proves that the condition for overcoming the crisis of democracy is the development of civil society along the lines suggested by Arendt's concepts of public sphere and political freedom.

Keywords: revolution, freedom, action, politics, public sphere, the social.

\section{REFERENCES}

Arendt, H. (2000). Vita Activa or Active Life. (V. Bibikhin, Trans.). Saint Petersburg: Aletheia. (Original work published 1958). (In Russian).

Arendt, H. (2002). Between Past and Future. (V. Chernyak, Trans.). Kyiv: Dukh i Litera. (Original work published 1961). (In Ukrainian)

Arendt, H. (2011). On Revolution. (I. Kosich, Trans.). Moscow: Publishing House "Europe". (Original work published 1963). (In Russian).

Beck, U. (2001). What is Globalization? (A. Grigoriev, V. Sedelnik, Trans.). Moscow: ProgressTraditsia. (Original work published 1999). (In Russian).

Benhabib, S. (1996). The Reluctant Modernism of Hannah Arendt. Thousand Oaks: Sage Publications.

D’Entréves, M. P. (1994). The Political Philosophy of Hannah Arendt. London: Routledge.

Keane, J. (2001). Democracy and Civil Society. (M. Abramov, Trans.). Moscow: Progress-Traditsia. (Original work published 1988). (In Russian).

Magun, A. (2008). Negative Revolution: Deconstruction of Political Subject. Saint Petersburg: European University Press in Saint Petersburg. (In Russian).

Shell, J. (2006). Introduction to Hannah Arendt's On Revolution. New York: Penguin Classics.

Tocqueville, A. de. (1992). Democracy in America. (V. Oleinik, E. Orlova, I. Malakhova, I. Ivanyan, B. Vorozhtsov, Trans.). Moscow: Progress. (Original work published 1835). (In Russian).

Wellmer, A. (2000). Arendt on Revolution. In D. Villa (Ed.), The Cambridge Companion to Hannah Arendt (pp. 220-244). Cambridge: Cambridge University Press.

Article arrived: 23.10.2018

Accepted: 27.11.2018 